\title{
Cheating at the market place - impressions from Micah 6:9- 16
}

W J Wessels

(Unisa)

\begin{abstract}
Cheating at the market place - impressions from Micah 6:9-16

Reading an ancient text is a problematic endeavour. In this article, Micah 6:9-16 is read as part of the final composition of the book of Micah. The text is read with an openness to the impressions it creates on a modern reader, like the researcher. These impressions are then related to modern day context, both church and society.
\end{abstract}

\section{INTRODUCTION}

Over the years, the book of Micah has posed a real challenge to biblical scholarship. The book of Micah is not unique in this regard, but is one example of many endeavours of reading an ancient text with some sense of understanding. Approaches of reading and understanding the biblical texts, and in this regard, the text of Micah, has varied somewhat. The result of this is the offering of a variety of solutions to understanding Micah.

The issues of this essay is to offer a reading of Micah 6:9-16 that would hopefully make some sense to readers who wish to understand and to relate the Bible to their world of reference. Biblical scholarship has to ask critical questions and confront difficult and sometimes unintelligible issues with the aim of offering some solutions. Ancient texts, more than desired, pose these challenges and Micah is not the exception. Scholarship should however suggest constructive readings of texts.

\section{PRELIMINARY REMARKS ON MICAH 6:9-16}

Over time scholars have offered different ways of structuring Micah 1-7. They differ mostly in their ways of dividing chapters $1-5$, but seldom in the division of chapters 6 and 7 , which they group together. The general consensus is that chapters $1-5$, in some or other sense, form a unit and so also 6 and 7 (Mays 1976:1-12). In the research of Van der Woude (1976), chapters 6 and 7 are even regarded as coming from another person or prophet, being called Deutero-Micah. Van der Woude has put a strong case for this and has offered a number of convincing arguments to back up his view. He places this prophet in times earlier that the prophet Micah. Opinions, however, differ much on the composition of the book Micah, and 
on the dating of the different sections and subsections (cf Gowan 1998:5152; Blenkinsopp 1996:92-93; Gottwald 1985:375-376 and also Mason 1991).

Recent exposure to the commentary of McKane (1998) on Micah has left me rather unsatisfied, in regard to him offering a reading of the biblical text that could be appropriated to or related to our world of understanding. Admitted, making sense of the Micah text is, in many instances, a hypothetical endeavour, but a needed one within the frame of reference of the church and society. In all faimess, it should be stated that this does not seem to be McKane's aim in his explication of the text.

McKane is an excellent and learned scholar, highly respected among researchers for his painstaking thoroughness and linguistic skills. Reading his exposition of Micah 6:9-16 quickly creates the awareness that the text offers many difficulties to by considered. His research has highlighted the many problematic tendencies in the history of research on Micah 6:9-16 (McKane 1998). This knowledge offers very little assistance to a coherent reading of the section, however, it serves as a necessary restraint not to be over-optimistic or over-simplistic in determining the meaning of 6:9-16.

McKane regards Micah 6:9-16 (excluding noticed additions) as a weak imitation of the prophecies of the $8^{\text {th }}$ century prophet Micah. He proposes an exilic or post-exilic dating when, according to him, circumstances in Jerusalem reflected traits similar to the Mican period (McKane 1998:14). Other scholars (eg Rudolph 1975:120), however, claim Micah to be the author of this section. There has never been consensus on this matter, and there would probably never be. Fact is, the final redaction or composers of the book of Micah have offered chapters 1-7 as a collection of texts belonging together and preserved as such by tradition. The authority rendered to this composition was surely due to the linking to the $8^{\text {th }}$ century prophet Micah. It therefore seems reasonable to read Micah 6:9-16 in the context of the final composition of the book. The text in 6:9-16 seems to reflect circumstances, in supposedly Jerusalem (the city not named in the text), of which Yahweh did not approve. What is learned from 6:9-16 about conditions in Jerusalem also does not seem out of touch or inconsistent to what we already know from Micah 1-3. However, even although one reads 6:9-16 in context with the rest of the book of Micah, it is not possible to pinpoint an exact date, and therefore a specific society in which one can place and read this section. Even if one concedes to reading it as referring to post-exilic times in Jerusalem (cf McKane 1998:20; Wolff 1982:xxxvi), it remains vague. The general tenor of the section is vague and seems applicable to any of many periods in time of the history of Jerusalem.

Perhaps it is wiser to allow the text to create its own impressions, keeping in mind that whoever was responsible for collecting, preserving and structuring the text of Micah, wanted people to read it as in line with 
the thoughts of the prophet Micah. What follows in this article is firstly a more general exposition or reading of the text of Micah 6:9-16, and then an endeavour to explicate the impression created by the text as perceived by the researcher of this article (cf also Clines 1995:166-169).

\section{CHAPTER 6:9-16: DESTINY OF AN UNJUST CITY}

The section under scrutiny is preceded by Micah 6:1-8, a section in the form of a lawsuit. It seems to be a well rounded unit, in which Yahweh takes his people to task. A new section begins with verse 9 and extends to verse 16. In this section the city with her inhabitants are addressed, and, as is often the case in the book of Micah, the word "hear" or "listen" is used as a structural device indicating the beginning of a new section. While it is possible to take this section as a continuation of the lawsuit in verses $1-8$, providing the verdict section lacking in the previous section, verse 8 forms the climax of the lawsuit-section and verse 9 introduces a section in which Yahweh engages in a new encounter with the city and her inhabitants.

Besides the clear indications of a new section commencing in verse 9, one should not overlook its connection to the previous section. The beginning is similar to the call to "hear" the "voice" of Yahweh. Whereas reference to the lack of justice in verses $1-8$ is vague, in verses $9-16$ the injustices are made explicit.

This section (verses 9-16) is an oracle of judgment, and contains an announcement of the misconduct of the city and its inhabitants, as well as a section which indicates the consequences of this. The section can be divided as follows: Verse 9, the link with the previous section and the ensuing section; verses 10-12, the transgressions; verses 13-15, the judgment, and finally verse 16 , which substantiates the judgment and indicates the consequences.

Verse 9, thus, functions as a hinge between the preceding unit and the speech of Yahweh from verse 10 onwards. It is a difficult verse to translate and scholars have proposed emendations to the Hebrew text.' The verse focuses on the "voice of Yahweh" which is directed at an anonymous city. Shaw (1993:180, 190-92) identifies the city as Samaria, whilst Schuman (1989:161) is of opinion that the reason no city is explicitly named, is to indicate both Jerusalem and Samaria. However, Jerusalem, where Micah delivered his oracles, seems the most likely option.

1 The suggestion that "he will see" (vir eh) in the Masoretic text (MT) should be changed to "to fear" (yir 'a) is generally accepted. Another major change and redivision of the text at the end of verse 9 and the beginning of verse 10, in which many follow Wellhausen, is the change of "umi ye 'adah ( ir)" to "umo'ed ha 'ir" to read "and assembly of the city" with "matteh" to mean "tribe". This suggestion is plausible and makes good sense within the context with the focus on the city (cf Allen 1976:375; See also Hagstrom 1988:93). 
The reference to the unnamed city is followed by an independent sentence very much like a proverb, announcing a very important truth: "wise is the one who fears your name". This almost sounds like a greeting by the prophet when he addresses this city and its people. They are called upon to hear the voice of Yahweh. Following this greeting, the traditional invocation in the Book of Micah to pay attention, ("listen"- shime 'u), is directed to the tribe and the people assembled in the city. If the intended city were Jerusalem, then the tribe was probably Judah. One could imagine an assembly of people in Jerusalem, gathered for one or other occasion. The city was the major assembly point for people who came to worship and bring their sacrifices (cf verses 6-7), and it was a very important centre for trade, not to mention its political importance. Thus, the city was a convenient location where the prophet could call on the people to come and hear what Yahweh had to say about matters which concerned them. It must have been on such an occasion that the prophet took the opportunity to speak to the people on behalf of Yahweh about their misconducts. This is contained in verses 10-12, where specific charges are laid against the inhabitants of the city. These are the misconducts of the people in the marketplace and the deceitful rich.

Verse 10. After the suggested textual emendations at the beginning of this verse, a further change is proposed, to read: "Can I tolerate ${ }^{2}$ (or overlook) the wrong measure, ${ }^{3}$ ill-begotten treasures and the false measure (ephah), which is cursed?" The obvious answer is no. The ephah was used to measure dry products and the bat for measuring liquids. The cheating of customers in the market place, by using smaller measuring utensils than the agreed standard and the making of a profit in this way, was a disgrace.

Verse 11 elaborates on the misdeeds in the market place, asking if Yahweh would approve of the person who used a fraudulent scale and a bag containing false weights. Once again the obvious answer is an emphatic no; he despises such deceitful practices. In this regard the law codes from Leviticus 19:35, 36 and Deuteronomy 25:13-16 would be applicable. According to Amos 8:4-6, the poor suffer most when these exploitive practices are practised. Even the world of commerce should reflect the justice spoken of in Micah 6:8.

Verse 12.s The focus shifts to the rich of the city, filled with, or addicted to violence. The rich are the powerful ones in the city and use

\footnotetext{
${ }^{2}$ A reading of "can I tolerate" (ha'essah)) is preferred to "is there?" (ha ish) of the MT; cf Shaw (1993:162, footnote 5).

3 Allen (1976:375 footnote 54), changes the MT "house of the wicked" (bet rashah) to "bat resha"", meaning "wrong measure" which fits the context.

${ }^{4}$ The $\mathrm{Pi}^{\prime} \mathrm{el}$ form of the verb is suggested. A literal translation would then be: "Can I regard (someone) pure with..."

5 Many scholars propose a re-arrangement of the verses, but it seems unnecessary. Cf Shaw (1993:163 footnote) for a variety of proposed changes to the text.
} 
their power to oppress ordinary people. As it became clear in chapters 2 and 3, they would not even refrain from violence to satisfy their lust for more property and personal gain. Many others have become victims of their aggression and lost their land and personal freedom. Hence Micah 3:10 refers to the building of Jerusalem with blood and acts of violence. In this particular context, the focus is on the exploitation in the everyday lives of those people who usually go unnoticed. The inhabitants of the city are characterized as liars, people who are deceitful. Alfaro (1989:71) regards the "inhabitants" as "...the upper classes of urban society, including the princes, judges, and other leaders". In this regard, the courts are of particular relevance. Here truth should prevail instead of lies. Prophets are also expected to speak truth and not lies (cf chapter 3). A prophet who speaks "deceit" (sheqer) is considered to be a false prophet ( $\mathrm{cf}$ in this regard also Overholt 1970). In this section, it is the city of Jerusalem, the seat of political power, centre of economic and judicial life, that is regarded as deceitful. It is on account of a comupt society that the city is the target of accusations and will suffer the dire consequences.

In verses 13-15 punishment is announced by means of "futility curses" (Hillers 1984:82), indicating that no endeavours would bear fruit. These are similar to the curses from Leviticus 26:14-16 and Deuteronomy 28:30-31; 38-40 (cf also Hos 4:10; 8:7; 9:11, 12, Am 5:11) and are related to the covenant where promises result from obedience, and threats are incurred on account of disobedience. Micah, most probably, had this covenantal setting in mind when he uttered these curses (Allen 1976:379).

In verse 13, Yahweh, in the first person, announces that he will make the people sick by smiting them. "You" should be taken as a collective for the people of Judah and Jerusalem. Exactly what this means is not clear, but one should perhaps think in terms of military activity, like the invasion of an enemy that will strike the people a sickening blow. This thought is strengthened by reference to the sword in verse 14 and the humiliation of the people mentioned in verse 16. During the ministry of both Micah and Isaiah, the forces of Assyria posed a constant threat to Judah and Jerusalem. It will, therefore, be difficult to decide on a specific occasion in this instance. One of the major events, to name one that would fit these circumstances that shook the people of Judah, was the siege of Jerusalem in 701 $\mathrm{BCE}$ by Assyria. The punishment because of the sins committed ( $\mathrm{cf}$ verses 10-12) would leave Judah and Jerusalem desolate.

In the following verses, the content of their misery is expressed by means of the "futility curses". Everything seems to come to nothing. This

\footnotetext{
${ }^{6}$ Allen (1976:376 footnote 58), argues in favour of retaining the MT and not following the LXX as many do. He regards the occurrence of the two verbs "be sick" and "strike" as an "idiomatic juxtaposition of the two verbs". He refers to Jeremiah 10:19; 14:17; 30:12 and Nahum 3:19 as justification for this decision.
} 
applies to eating, saving, sowing and even their efforts to produce oil from olives and wine from the grapes.

Verse 14. Both verses 14 and 15 begin with "you" ('attah) to emphasise the fact that it is the people of the city who are targeted for the punishment of Yahweh. The first of these curses states that they shall eat, but will not be satisfied by what they have eaten. They will be beset by a gnawing hunger. What is meant in the second part of the verse is unclear, but it conveys the same idea of futility. They will attempt to store up things, but they will not manage to save anything by this effort. If, by chance, however, they manage to save something, it would be handed over to the sword. ${ }^{7}$ This probably implies invasion by an enemy and the seizure of all that was saved.

Verse 15. The pleasure of seeing and enjoying the fruit of one's labour will not be allowed. It costs toil to sow, but the opportunity to reap will be denied. The same would apply in the case of the tiresome labour of treading the olives and the grapes. The end products, oil and wine, will not be enjoyed. This means, no anointing with oil and no drinking of the wine. This curse on the agricultural life of the Judean society was clearly a severe one. The announcement to an agrarian society that they would not enjoy the fruit of their labour is devastating. Allen (1976:380) refers to the resemblance between this oracle, Leviticus 26:16 and Deuteronomy 28:33, with regard to the enemies eating the fruit of their labour. A threat to the harvest by pestilence or an enemy can be devastating to a community. In the light of the frequent implication of such invasions in the oracles of Micah, Allen. argues in favour of enemy invasion in this regard. If an invasion of an enemy is indeed implied, it is terrible to think that an invading enemy will enjoy all the fruits of their labour. Though an invading enemy may be implied, the possibility, however, of natural disasters causing draughts and famine, as in the time of Ahab and Elijah, should not be excluded.

Verse 16. The reason for the punishment is substantiated and followed by a proclamation of judgment. These people are blamed for observing the statutes of Omri and all the practices of the house of Ahab. In addition, they are blamed for following the counsel of these two kings. Literally, it could be translated "...and you have walked according to their counsel". The reference to Omri and Ahab causes many to deny Micah's authorship of the whole of chapter 6 , due to the fact that they were kings ruling in the Northern Kingdom of Israel, while Micah ministered in Judah in the South. Others regard verse 16 as a later addition or reinterpretation. Still others argue in favour of maintaining verse 16 as part of the speech commencing in verse 9 (Hagstrom 1988:93).

It is not clear in what sense Omri should be regarded as a reference point for the transgressions of the inhabitants of Jerusalem. Not much is

\footnotetext{
${ }^{7}$ Shaw (1993:163) maintains that if someone manages to flee, death will come by the sword; Schuman (1989:141) fosters the idea of bringing life, giving birth.
} 
said about him, except that he is known for making Samaria his capital and for his alliance with the king of Tyre, through Jezebel's marriage to his son Ahab. Reference to Ahab in the present context of economic misconduct (verses 10-12), concerns the Naboth incident rather than his association with the Baal religion. In 1 Kings 21 , his offence against Naboth, in denying him his right to his vineyard, is discussed. This is a clear example of abuse of power; self-enrichment to the detriment of another, greed and injustice. The people are condemned for pursuing these policies rather than following the counsel of Yahweh, as verse 8 requires. ${ }^{8}$ These representatives of the Northern Kingdom and their fate should serve as a warning to the neighbouring Kingdom of Judah and its people (cf 1:5).

The final word of judgment to these people is that Yahweh will abandon them to ruin. The punishment will have a devastating effect on the city, a disturbing sight to see. For the inhabitants it will also result in humiliation, because in the international arena they will be scorned by other nations. They will lose their reputation amongst the neighbouring nations.

There are not many indicators as when to date this oracle or the chapter in general. If one regarded it fitting into the Mican context, then it should be read against the background of Assyria as the dominating power. Closer pinpointing of a time is not possible, and would be nothing more than speculation. The timeless nature of this chapter has the advantage that it can be actualized repeatedly within new contexts.

\section{IMPRESSIONS FROM MICAH 6:9-16}

The text draws attention to circumstances in a city, most probably Jerusalem, where commerce is thriving, and specifically the market-place is in focus. But it is exactly here in the market-place that injustice rules the day. Ordinary people are cheated out of their fair share by dishonest merchants. False measuring is practised by people, who are deceitful in nature, who are living a lie. Their actions are described as violent. This closely links with chapters 2 and 3 of Micah.

The prophet, as spokesperson of Yahweh, speaks from the vantage point of the powerless, those who have very little. These people are at the mercy of the "haves". Whereas deprivation of land was the focus of chapter 2 (Wessels 1997:528-544), the market-place is in focus here. What is disturbing is that the ordinary person who is in need of food for survival, is affected in this regard. Those who have very little, are deprived of the little they can afford by those who have and in the process is getting more at the expense of these people. The rich become richer and the poor poorer.

The issue does not so much revolve around the fact that there are rich people and ordinary people, but how these riches were obtained. The key

\footnotetext{
${ }^{8}$ The same verb "halach- to walk" is used in verses 8 and 16 .
} 
issue for the prophet is dishonesty (sheqer). People are cheated out of their land, and therefore denied the opportunity to earn a living (cf 2). In chapter 3 the leadership, the prophets and the priests are blamed for their lies and deceit (cf Wessels 1997:125-135). The same tendency of deceit is the focus of 6:9-16 and this Yahweh will not tolerate. People in this city are rich and powerful because of lies and deceit. To maintain their power and control, they will not hesitate to use violence. From this passage it seems that the merchants are not only the rich and powerful people in the city who control the deceitful commerce in the market place, but that they are also the ones who possess the fields and vineyards and the produce it delivers. According to verse 15 they sow seed, press olives and tread grapes. They are the rich and powerful in the city, and also the powerful and oppressive landlords. It is known that many Israelites had lost their land over time, became impoverished, and finally enslaved. These social imbalances disturbed the prophets of Yahweh and evoked condemning responses from them. It is perhaps also hinted, by reference especially to Ahab, that the land and vineyards that bring forth the crops, the olives and the grapes, illegally came into their possession through their greed and violence. Once again an indication of power abused to the detriment of others.

Another impression created in this passage, is the focus on Yahweh as the ultimate power. Punishment is the logic outcome of disobedience towards Yahweh. These powerful people might think that they are in command of everything, but Yahweh is the ultimate power. All their effort and action will bear no fruit and come to nothing, if Yahweh decides to act against them. It is in his power to cut off the means of produce, and therefore leave them empty handed in the market place, with nothing to supply. It is also in his power to raise up a nation in battle that will demolish them and make them the laughing stock of the nations.

\section{CONCLUSION}

It seems clear from this, and other sections from the book of Micah, that the powerless can not match the power of the rich and powerful. Their only hope lies with Yahweh, who will act on their behalf. The prophet, however, makes it clear that the market place is not excluded from the concerns of Yahweh. What happens in the economic sphere of society concerns him and he will not tolerate any injustice. Therefore, the prophet voices the proclamation of Yahweh that he demands justice and that disobedience will have negative consequences. Yahweh hates deceit and will not tolerate it. Those who regard their riches and power as sufficient and a source of comfort and strength, should reconsider their position. They should realise the limitations of their means of power. In confrontation with the ultimate power, their efforts will come to nothing. 
The proclamation in Micah 6:9-16 serves as the prophetic voice in the society. It can be Micah's society, but it need not be. The general tone of the passage allows this voice to reach even further, to our contemporary societies. Yahweh will not tolerate injustice in any form, whether it is cheating in the market-place, abuse of ordinary people, violence, oppression or illegal possession of means. Words in this passage such as hate, not tolerate, violence, deceit, destruction, ridicule and humiliation, to mention a few, give indication of strong emotions and actions. They sustain the aversion of Yahweh about such deeds as voiced by the prophet.

The prophetic voice today should also not be silent about similar injustices in our society. There is a need for it to be heard. It is the knowledge of who Yahweh is, the fear of Yahweh (in the sense of honour and respect), and the close relationship between worshipper and Yahweh, that creates the need and urges one to speak out and oppose injustices. The prophetic word should be voiced in the market-place, in government and government structures, in courts and judicial structures, in churches and their structures, in society as a whole. Questions should constantly by posed on issues such as prosperity and poverty, the reasons for its existence, how prosperity is sustained, how it can be balanced and how it relates to worshipping Yahweh. The prophet Micah, and prophets like him, would claim that the implications of worshipping Yahweh are not to be restricted to covenant communities, to use the Old Testament phraseology, or modern day church and religious people, but should reach all corners of society. Justice is not only a church matter, but a societal concern. In this however, the church and religious people should play a decisive and leading role, living it, proclaiming it.

The fruit of comption is not prosperity and power, but destruction and humiliation. The proverb is verse 9 seems an apt conclusion to this paper: "The one who fears your (Yahweh's) name is wise."

\section{Consulted literature}

Alfaro, J I 1989. Micah. Justice and loyalty. Grand Rapids: Eerdmans (ITC).

Allen, L C 1976. The books of Joel, Obadiah, Jonah and Micah. Grand Rapids: Eerdmans (NIC).

Blenkinsopp, J 1996. A history of prophecy in Israel. London: SPCK.

Clines, D J A 1995. Language as Event, in Gordon, R P (ed), The Place Is Too Small For Us. Winona Lake, Indiana: Eisenbrauns.

Gottwald, N K 1985. The Hebrew Bible. A socio-literary introduction to the Old Testament Philadelphia: Fortress.

Gowan, D E 1998. Theology of the Prophetic Books. The Death \& Resurrection of Israel. Louisville, Kentucky: Westminster John Knox.

Hagstrom, D G 1988. The coherence of the book of Micah. A literary analysis. Atlanta:

Scholars Press.

Hillers, D R 1984. Micah. Philadelphia: Fortress (Hermeneia). 
Mason, R 1991. Micah, Nahum, Obadiah. Sheffield: JSOT.

Mays, J L 1976. Micah. London: SCM (OTL).

McKane, W 1998. Micah. Edinburgh: T\&T Clark.

Overholt, T W 1970. The threat of falsehood. A study in the theology of the book of Jeremiah. London: SCM.

Rudolph, W 1975. Micah, Nahum, Habakuk, Zephanajah. Gütersloh: Gütersloher Verlagshaus.

Schuman, N A 1989. Micah. Kampen: Kok.

Shaw, C S 1993. The speeches of Micah. A rhetorical-historical analysis. Sheffield: JSOT.

Van der Woude, A S 1976. Micha. Kampen: Kok (POT).

Wessels, W J 1997a. Wisdom in the gate: Micah takes the rostrum. OTE 10/1, 125-135.

-, 1997b. Conflicting powers. Reflectoins from the Book of Micah. OTE 10/3, 528-544.

Wolff, H W 1982. Micah. Neukirchen-Vluyn: Neukirchen. 